\title{
Economic analysis of forced tomato production with regard to the intensity of production
}

\author{
Dorogi, D. A. \& Apáti, F. \\ University of Debrecen, Faculty of Economics and Business, Institute of Management Sciences \\ Author for correspondence: aniko.dora.dorogi@gmail.com
}

\begin{abstract}
Summary: We assessed the cost/income conditions of forced tomato production and return conditions of the growing technologies by investmentprofitability analysis. Horticultural sectors generate significant added value and employ a large number of workers per unit area; however, these sectors cover only $4 \%$ of agricultural areas. Regarding the use of capital and labour, forced vegetables are the most intensive horticultures with several development potential and reserves to gain better quality and a more efficient farming. One of the most prominent forced cultures is table tomato produced under different types of forcing equipment in Hungary: traditional, low-height plastic tunnel; large-atmospheric, block-based plastic tunnels and various greenhouses. The prime goal of my thesis is to specify the economic efficiency of each type and to choose the most efficient one by the complex economic assessment of plastic tunnels, block-based plastic tunnels and greenhouses with the most advanced technologies. Results of the economic analysis suggest that the most efficient production method is the modern, Dutch greenhouse technology; however, this statement is not backed by every indicator: each type has its own advantages and disadvantages. Regarding the future, the installation of such types or even (in the technical sense) more modern growing technology may be considered as a prospect for capital intensive and larger businesses.
\end{abstract}

Dorogi, D. A., Apáti, F. (2019): Economic analysis of forced tomato production with regard to the intensity of production. International Journal of Horticultural Science 25(1-2): 15-21. https://doi.org/10.31421/IJHS/25/1-2./2911

Key words: forced tomato production, greenhouse, block-based plastic, cost/income condition, investment-profitability analysis

\section{Introduction}

Regarding agriculture in Hungary, fruit and vegetable production is the third most prominent sector on the basis of production value. Horticultural sectors don't have significant influence regarding their territories; however, they have and gain significant added value per unit area (Czerván, 2014).

Based on preliminary data, agriculture contributed to GDP by $3.0 \%$ in 2015 . Agriculture represented $3.6 \%$ in domestic gross value-added, $4.2 \%$ in investments and $4.8 \%$ in employment (AKI, 2016).

Based on data by the Hungarian Central Bureau of Statistics, total gross output of agriculture was HUF 2454 billion in 2015 which is almost tantamount to the previous year's result.

Plant products accounted for 58\%, more than half of HUF 2454 billion while livestock products and agricultural services represented $35 \%$ and $7 \%$, respectively.

Within plant products, the value of horticultural products contributed to total gross domestic output of agriculture by approximately $10 \%$. Vegetable production area has been stagnating at 75-80 thousand hectares for a decade, yield is fluctuating around 1.5 million tonnes (Kicska \& Apáti, 2015). Estimated data show that there are areas of 2 500-2 600 ha under forced production which is considered rather technical area. Due to dual use, technological area is around 3700 ha, but it produces quarter of the production. Pepper production is performed on most of this territory (Kicska, 2015). In Hungary, the level of technology in horticulture is lagging behind the European countries. Forced plants gains the higher revenue per unit area in horticulture. There is great potential in forced vegetable production. It is one of the fastest developing sector and possible to develop rapidly (AKI, 2016). A stagnating or slightly downward tendency can be seen in forced pepper territories for 10 years, but yields don't decrease significantly. Production was under 400 ha in 2016, but yield is predicted to be around 130 thousand tonnes. This quantity would be sufficient to meet the Hungarian customer demand and a small part of it is exported to the Eastern countries (Ledó, 2016).

The prime goal of my thesis is to specify how efficiently and - on a longer basis - under what economical parameters forced vegetable production may be completed under different forcing equipment. My objective answers the question what type of growing method proves the most effective, what economic advantages and disadvantages of each method have and what method is recommended from the economical point of view. Regarding the above-mentioned goals, the following questions were raised to specify my detailed objectives: i) how do the input/output conditions and production value change depending on the type of the forcing equipment, ii) what farming output and efficiency feature each growing method, and iii) what invested capital need do technologies have and how can long-term profitability and return conditions be characterized?

\section{Materials and methods}

To complete this thesis, we carried out primary and secondary data collection including processing literature, personal data collection and ongoing professional consultancy. During conducting the thesis, we used data from farms with high-quality production. We carried out cost-benefit and 
investment-profitability analysis for each technology. Consideration of economic and legal circumstances and prediction as much as possible are crucial factors for wellfounded economic decisions so we carried out sensitivity analysis to deal with uncertainties in the economic environment and calculations. Processing of data collected - similarly to Apáti (2009) and Szőllősi (2008) - was completed using Excelbased simulation deterministic model. The basic principle of data processing was the size unit for the results $\left(1000 \mathrm{~m}^{2}\right)$, economic conditions were given using this unit. We calculated different cost, value and income categories at sectoral level and efficiency indicators using production costs and production values. After we specified profitability, effectiveness and efficiency of each technology by the evaluation and interpretation of the abovementioned categories and indicators.

It is important to emphasize that calculations were performed only at sectoral level, so costs don't include overhead costs at management level and revenue covers only turnover (financial operations revenue and extraordinary revenue are excluded). Several indicators are available to evaluate efficiency of investments. However, several authors (Horváth, 1997; Pfau, 1998; Tétényi, 2001) highlight dynamic investment-efficiency indicators which consider the time value of money compared to static indicators.

According to Castle et al. (1992), and Brealey \& Myers (2005), one of the most widespread and frequently used indicators for the analysis of investments is NPV (Net Present Value), we also opted for this method. Dynamic indicators used in the analysis include NPV (Net Present Value), DPP (Discounted Payback Period) and IRR (Internal Rate of Return, return on capital). After completing the cost-benefit and investment-efficiency analyses, we carried out sensitivity analysis to perform a complex economic analysis. During elasticity analysis, we reveal what influential factors affect economic result more significantly and to what extent NPV for investment changes in case of favourable changes. Critical value assessment seeks to ascertain what yield, quantity and price conditions are required to gain a minimum level of longterm efficiency in business environment and production technology (Apáti, 2007).

Different plan versions can be established by scenario analyses (optimistic, realistic, pessimistic). Thereby we can analyse how efficiency changes if certain factors of the business environment are probably more favourable or less favourable than expected.

\section{Results and discussion}

Forced tomato production is basically performed under greenhouses, most of the investments for the future are toward building greenhouses. However, there are still examples of plastic-covered tunnel subdivided into traditional, low-room or block-based.

It is important that there is no significant difference in production technology regarding the types studied, forced tomato production is performed in growing medium (rockwool) in all the three types. There is heated production in all the three types of growing technology. It is thermal water that is the most cost-effective these days. The research was basically for different types of growing technology: low-cove traditional plastic tunnel, high-cove, block-based tunnel, and Dutch greenhouse with cutting-edge technology.

\section{Investment costs}

There are significant differences between investment costs during the research of the growing technology. Total investment cost for low-height plastic tunnel per 1 hectare is HUF 100000 000, for block-based tunnel is HUF 180000000 while greenhouse has the highest investment capital need (HUF 300000 000).

\section{Cost/income relations}

There are significant differences between the outputs and efficiency of the growing technology (Table 1): traditional plastic tunnel $-31 \mathrm{~kg} / \mathrm{m}^{2}$, block-based plastic tunnel -46.7 $\mathrm{kg} / \mathrm{m}^{2}$, greenhouse $-57.4 \mathrm{~kg} / \mathrm{m}^{2}$. Traditional plastic tunnel has the poorest output due to the outdated style. Its specific yield is $34 \%$ lower than the block-based plastic tunnel and $46 \%$ lower than the greenhouse.

Yield under block-based plastic tunnel approaches the yield under modern greenhouse. However, it is still $20 \%$ lower than greenhouse. Due to differences between yields, it should be noted that growing technology with higher yield generates higher revenue.

A revenue of HUF $6879 / \mathrm{m}^{2}$ under traditional plastic tunnel is $26 \%$ lower than under block-based plastic tunnel and $43 \%$ lower than greenhouse. In terms of scale, the difference in revenue between block-based plastic tunnel and greenhouse is as much as the difference between traditional and block-based plastic tunnel. Higher yield under greenhouse generates higher revenue that is due to the state-of-the-art growing equipment. However, revenue is also affected by the length of the growing season. In a longer growing season, the first harvesting takes place earlier entailing higher selling price and revenue - even in case of the same amount of annual yield. Therefore, increase in revenue under state-of-the-art equipment is in part due to the fact that the rate of yield to be harvested earlier at higher selling price is increasing.

Results should be interpreted at sectoral level. The difference between the highest and the lowest revenue is HUF $5134 / \mathrm{m}^{2}$. Yield and revenue are increasing due to modernisation of the growing technology and production intensity.

Higher yields and production under state-of-the-art equipment generate other costs, as well. Table 1 shows that the difference in revenue is higher than in direct cost. The amount of direct cost is nearly the same under traditional and block-based plastic tunnel. Traditional plastic tunnel with a total direct cost of HUF $6080 / \mathrm{m}^{2}$ generates a yield of 31 $\mathrm{kg} / \mathrm{m}^{2}$ while block-based plastic tunnel with a total direct cost of HUF $6753 / \mathrm{m}^{2}$ generates a yield of $46.7 \mathrm{~kg} / \mathrm{m}^{2} .50 \%$ higher yield requires only $10 \%$ higher indirect cost. Total direct cost is higher for modern greenhouse, it is HUF $8720 / \mathrm{m}^{2}$.

Production under block-based plastic tunnel generates $10 \%$ higher cost and 50\% higher yield than traditional plastic tunnel. Regarding block-based plastic tunnel, its total direct cost and its yield is $23 \%$ lower than under modern greenhouse. Therefore, direct production cost is quite high under traditional plastic house (HUF 196/kg) while it is nearly the same under greenhouse and block-based plastic tunnel (HUF 144-152/kg) and 20-25\% lower than under traditional plastic tunnel. 
Table 1. Output and efficiency for growing technologies

\begin{tabular}{|c|c|c|c|c|}
\hline Name & Unit & Traditional plastic tunnel & Block-based plastic tunnel & Modern greenhouse \\
\hline Yield Class I. & $\mathrm{kg} / 1000 \mathrm{~m}^{2}$ & 26930.1 & 40280.7 & 49421.4 \\
\hline Class II. & $\mathrm{kg} / 1000 \mathrm{~m}^{2}$ & 4132.5 & 6499.0 & 7978.6 \\
\hline TOTAL YIELD & $\mathrm{kg} / 1000 \mathrm{~m}^{2}$ & 31062.6 & 46779.7 & 57400.0 \\
\hline Average selling price Class I. & $\mathrm{HUF} / \mathrm{kg}$ & 252.9 & 252.9 & 252.9 \\
\hline Class II. & $\mathrm{HUF} / \mathrm{kg}$ & 151.8 & 151.8 & 151.8 \\
\hline Turnover Class I. & $\mathrm{HUF} / 1000 \mathrm{~m}^{2}$ & 6299099.1 & 8349175.7 & 10952740.5 \\
\hline Class II. & $\mathrm{HUF} / 1000 \mathrm{~m}^{2}$ & 579968.2 & 837896.2 & 1060927.5 \\
\hline TOTAL TURNOVER & $\mathrm{HUF} / 1000 \mathrm{~m}^{2}$ & 6879067.3 & 9187072.0 & 12013668.0 \\
\hline PRODUCTION VALUE & $\mathrm{HUF} / 1000 \mathrm{~m}^{2}$ & 6879067.3 & 9187072.0 & 12013668.0 \\
\hline Total direct cost & $\mathrm{HUF} / 1000 \mathrm{~m}^{2}$ & 6080937.4 & 6753831.7 & 8720062.3 \\
\hline CONTRIBUTION MARGIN & $\mathrm{HUF} / 1000 \mathrm{~m}^{2}$ & 798129.9 & 2433240.3 & 3293605.7 \\
\hline Cash flow & $\mathrm{HUF} / 1000 \mathrm{~m}^{2}$ & 1498129.9 & 3533240.3 & 4793605.7 \\
\hline \multicolumn{5}{|l|}{ EFFICIENCY INDICATORS } \\
\hline Direct production cost & $\mathrm{HUF} / \mathrm{kg}$ & 195.76 & 144.38 & 151.92 \\
\hline Direct cost-profitability ratio & $\%$ & 13.13 & 36.03 & 37.77 \\
\hline Income level & $\%$ & 11.60 & 26.49 & 27.42 \\
\hline Cost level & $\%$ & 88.40 & 73.51 & 72.58 \\
\hline Return on sales & $\%$ & 11.60 & 26.49 & 27.42 \\
\hline Use of working time & hour $/ 1000 \mathrm{~m}^{2}$ & 1869.60 & 1577.70 & 1443.46 \\
\hline Revenue per working hour & HUF & 3679.43 & 5823.08 & 8322.85 \\
\hline Contribution margin per working hour & HUF & 426.90 & 1542.27 & 2281.75 \\
\hline
\end{tabular}

Source: Own data collection and calculation

The thesis is based on research at sectoral level, therefore we would like to emphasize and evaluate contribution margin out of the categories of income. Contribution margin doesn't consider overhead costs, it includes the output and profitability of the sector, covers only costs during physical processes of production and considers output performed there. Contribution margin under traditional plastic tunnel HUF $800 / \mathrm{m}^{2}$, while it is much higher under block-based plastic tunnel (HUF $2400 \mathrm{~m}^{2}$ ) and modern greenhouse (HUF $3300 \mathrm{~m}^{2}$ ).

The analysis of the efficiency indicators shows the improvement in direct cost-profitability ratio. Profitability for traditional plastic tunnel is quite low, it would continue to decrease significantly by overhead costs and the index would be close to zero. There is no significant difference between block-based plastic tunnel and modern greenhouse regarding profitability, so almost the same amount of profit may be gained by unit cost. Ultimately, contribution margin per unit are generates differences. This is due to the fact that production under greenhouse performed as much contribution margin as costs.

Cost-benefit analyses a one-year production period, so only their profitability can be deduced from the results. Such covered technologies can be used for years or even for decades. To make appropriate economic decisions, we should be aware of the capital need and return of investments in technologies. The suitable method is investment-profitability analysis.

\section{Profitability for investment}

Static and dynamic analyses are the principal methods for investment-profitability assessments. Dynamic methods consider the time value of money: if we had put our money invested in technologies in other risk-free investments (sovereign debts, or bank deposits), they may have yielded some profit in interest. In fact, profit higher than potential interest income of these investments is considered real profit in our investment (Kicska, 2015).

Figure 1 shows NPV of investments in technologies. Graphical representation of DPP (Dynamic Payback Period) shows when the investment returns, so when NPV becomes positive.

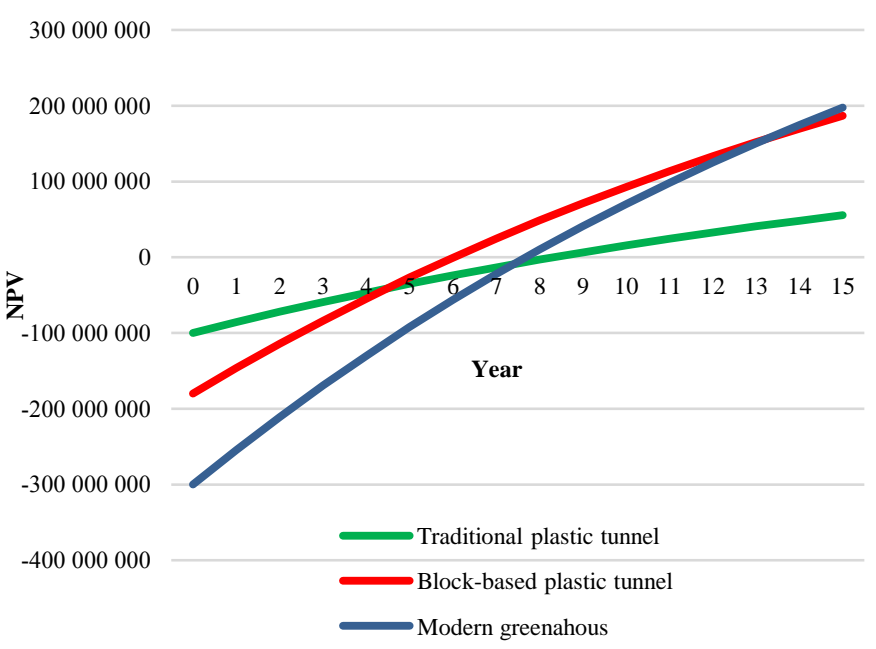

Figure 1. NPV under technologies dependent on time by $100 \%$ equity ( $\mathrm{r}=5 \%)$ Source: Own data collection and edition 
Table 2. Dynamic investment profitability indicators for technologies subsidised or non-subsidised at the end of the $15^{\text {th }}$ year $(\mathrm{r}=5 \%)$

\begin{tabular}{|l|c|c|c|c|c|c|}
\hline \multirow{2}{*}{ Name } & \multicolumn{2}{|c|}{ Traditional plastic tunnel } & \multicolumn{2}{c|}{ Block-based plastic tunnel } & \multicolumn{2}{|c|}{ Modern greenhouse } \\
\cline { 2 - 7 } & $100 \%$ equity & $50 \%$ subsidy & $100 \%$ equity & $50 \%$ subsidy & $100 \%$ equity & $50 \%$ subsidy \\
\hline Net Present Value (NPV) (HUF/ha) & 55500763 & 106497210 & 186738259 & 276738259 & 197559878 & 347559878 \\
\hline Profitability Index (PI) & 1.56 & 2.31 & 2.04 & 3.03 & 1.66 & 3.32 \\
\hline Internal Rate of Return (IRR) & $12.4 \%$ & $27.3 \%$ & $18.0 \%$ & $37.7 \%$ & $13.6 \%$ & $31.4 \%$ \\
\hline Discounted Payback Period (DPP) & 9th year & 4th year & 7th year & 3rd year & 8th year & 4th year \\
\hline
\end{tabular}

Source: Own data collection and calculation

Table 3. Favourable change of $1 \%$ on NPV

\begin{tabular}{|c|c|c|c|c|c|c|}
\hline Influential factor & \multicolumn{2}{|c|}{ Traditional plastic tunnel } & \multicolumn{2}{|c|}{ Block-based plastic tunnel } & \multicolumn{2}{|c|}{ Modern greenhouse } \\
\hline Original NPV & \multicolumn{2}{|c|}{5551} & \multicolumn{2}{|c|}{18674} & \multicolumn{2}{|c|}{19755} \\
\hline \multirow[t]{2}{*}{ Favourable change of $1 \%$ on NPV } & \multicolumn{2}{|c|}{ Change in NPV $\left(\mathrm{HUF} / \mathrm{m}^{2}\right)$} & \multicolumn{2}{|c|}{ Change in NPV $\left(\mathrm{HUF} / \mathrm{m}^{2}\right)$} & \multicolumn{2}{|c|}{ Change in NPV $\left(\mathrm{HUF} / \mathrm{m}^{2}\right)$} \\
\hline & Value $\left(\mathrm{HUF} / \mathrm{m}^{2}\right)$ & Rate $(\%)$ & Value $\left(\mathrm{HUF} / \mathrm{m}^{2}\right)$ & Rate $(\%)$ & Value $\left(\mathrm{HUF} / \mathrm{m}^{2}\right)$ & Rate $(\%)$ \\
\hline Yield & 634 & 11.43 & 885 & 4.74 & 1268 & 6.42 \\
\hline Price of tomato Class I. & 713 & 12.85 & 953 & 5.10 & 1311 & 6.64 \\
\hline Price of fertilizer & 41 & 0.74 & 52 & 0.28 & 64 & 0.32 \\
\hline Wage & 231 & 4.17 & 196 & 1.05 & 178 & 0.90 \\
\hline Investment cost & 99 & 1.79 & 179 & 0.96 & 300 & 1.52 \\
\hline Plant & 148 & 2.67 & 183 & 0.98 & 252 & 1.28 \\
\hline
\end{tabular}

Source: Own data collection and edition

When setting up a traditional plastic tunnel with lower investment costs - even if it has one-third investment capital need (HUF 100000 000/ha) - its return it expected later in case of investment by $100 \%$ equity. This conclusion cannot be drawn for block-based plastic tunnel and greenhouse. Blockbased technology returns at the $7^{\text {st }}$ while modern greenhouse returns at the $8^{\text {th }}$ year in case of investment by $100 \%$ equity.

NPV for traditional plastic tunnel is HUF $5550 \mathrm{~m}^{2}$ at the end of the $15^{\text {th }}$ year, while it is nearly HUF $19700 \mathrm{~m}^{2}$ for greenhouse. NPV for block-based plastic tunnel at the end of the $15^{\text {th }}$ year is HUF $18600 \mathrm{~m}^{2}$. There is not as significant differences in payback periods as in NPVs, investments return with a difference of 1 year. The return of invested capital is expressed by PI. For all the 3 technologies, PI values meets the acceptance criteria, but it is the most favourable for modern greenhouse. Modern greenhouse generates 1.66 times higher profit. This value for traditional plastic tunnel is 1.56 , for bockbased plastic tunnel is 2.04 , but investment cost should be considered. PI value shows that traditional plastic tunnel returns the investment cost of HUF $10000 / \mathrm{m}^{2} 1.56$ times, block-based plastic tunnel with the investment cost of HUF $18000 \mathrm{~m}^{2} 2.04$ times while greenhouse with the investment cost of HUF $30000 \mathrm{~m}^{2} 1.66$ times.

IRR shows a general return on equity. Values ranged from $12 \%$ to $18 \%$, so they exceeded the calculative interest rate significantly. Money invested in 0 . year would have returned under such investment rates during the life of investment.

Investment analysis was performed for each technology under subsidy of 50\%. Table 2 shows that subsidy generates 4-5 years less in payback period and NPV increased by $76 \%$ under modern greenhouse, by $48 \%$ under block-based plastic tunnel, by $92 \%$ under traditional plastic tunnel that was the worstperforming.

The question arises why greenhouse is getting more common for tomato forcing instead of block-based plastic tunnel. This is mainly because subsidy of $50 \%$ for investment dampens higher capital need for investment. The degree of change in indicators suggests that subsidy for investment has the least impact on the output block-based plastic tunnel. The payback period was also nearly halved for all growing technologies. Despite significant improvement in indicators for growing technologies, subsidy of $50 \%$ has the most favourable effect on modern greenhouse. Therefore, it is more rational in this subsidy environment to implement greenhouse.

\section{Sensitivity tests}

Cost-benefit and investment-profitability analyses are complemented by sensitivity tests. In order to make an economically well-founded decision on an investment, we must consider such environmental conditions that change the values in the average model, thus affect the results and efficiency of production.

One such type of sensitivity tests is the elasticity test. Elasticity indicates that how $1 \%$ change in the influential factors in some way will have an impact on the selected result category. In the thesis, we wanted to observe the change in NPV where yield, sales price, fertilizer price, wage, investment cost and plant price, as influential factors, change by $1 \%$ (Table 3). The elasticity test is capable of sorting the factors by their importance on profitability.

Table 3 shows the effect on NPV (on an absolute sum of 1 $\mathrm{m}^{2}$ and in \% compared to the original NPV). Selling price of tomato (Class I) generates the greatest change in NPV for all the three growing technology, i.e. it has the most significant effect on profitability. (Only the cost for harvesting was considered as variable costs in the test. When yield as an influential factor changed, the cost for harvesting changed parallelly.) Other significant influential factors include the change in wage. Other factors have an elasticity below them. The smallest effect was caused by the change in the price of fertilizers, it doesn't exceed $0.8 \%$ for the growing technologies. As a result of the study, it is also clear that the highest elasticity indicator was under traditional plastic tunnel, so the profitability of this technology responds the most sensibly to 
Table 4. Results of the scenario analysis

\begin{tabular}{|c|c|c|c|c|c|c|}
\hline & \multicolumn{6}{|c|}{ Traditional plastic tunnel } \\
\hline & \multicolumn{2}{|c|}{ Pessimistic } & \multicolumn{2}{|c|}{ Realistic } & \multicolumn{2}{|c|}{ Optimistic } \\
\hline & Non-subsidised & Subsidised & Non-subsidised & Subsidised & Non-subsidised & Subsidised \\
\hline PI & 0.79 & 1.59 & 1.56 & 3.11 & 3.76 & 7.53 \\
\hline IRR & $1.76 \%$ & $12.77 \%$ & $12.38 \%$ & $29.33 \%$ & $35.89 \%$ & $72.49 \%$ \\
\hline \multirow[t]{4}{*}{ DPP (year) } & $>15$ & 9 & 9 & 4 & 4 & 2 \\
\hline & \multicolumn{6}{|c|}{ Block-based plastic tunnel } \\
\hline & \multicolumn{2}{|c|}{ Pessimistic } & \multicolumn{2}{|c|}{ Realistic } & \multicolumn{2}{|c|}{ Optimistic } \\
\hline & Non-subsidised & Subsidised & Non-subsidised & Subsidised & Non-subsidised & Subsidised \\
\hline NPV (Ft/ha) & -110786028 & -20786028 & 186738259 & 276738259 & 540285474 & 630285474 \\
\hline PI & 0.38 & 0.77 & 2.04 & 4.07 & 4.00 & 8.00 \\
\hline \multirow{2}{*}{ DPP (year) } & \multicolumn{2}{|c|}{ Pessimistic } & \multicolumn{2}{|c|}{ Realistic } & \multicolumn{2}{|c|}{ Optimistic } \\
\hline & Non-subsidised & Subsidised & Non-subsidised & Subsidised & Non-subsidised & Subsidised \\
\hline NPV (Ft/ha) & -200785856 & -50785856 & 197559878 & 347559878 & 580001712 & 730001712 \\
\hline PI & 0.33 & 0.66 & 1.66 & 3.32 & 2.93 & 5.87 \\
\hline IRR & $-8.07 \%$ & $-0.56 \%$ & $13.65 \%$ & $31.47 \%$ & $27.52 \%$ & $56.45 \%$ \\
\hline DPP (year) & $>15$ & $>15$ & 8 & 4 & 4 & 2 \\
\hline
\end{tabular}

Source: Own data collection and calculation

Table 5. Results of critical value test

\begin{tabular}{|c|c|c|c|c|c|c|}
\hline & & $\begin{array}{c}\text { Value of } \\
\text { unfavourable } \\
\text { changes } \\
\text { (HUF/unit) }\end{array}$ & & $\begin{array}{c}\text { Value of } \\
\text { unfavourable } \\
\text { changes (HUF/unit) }\end{array}$ & & $\begin{array}{c}\text { Value of } \\
\text { unfavourable } \\
\text { changes } \\
\text { (HUF/unit) }\end{array}$ \\
\hline Yield & 9.47 & 2.94 & 23.11 & 10.81 & 17.96 & 10.31 \\
\hline Wage & 23.83 & 285.96 & 95.03 & 1143.60 & 111.11 & 1333.32 \\
\hline Investment cost & 55.50 & 55500000 & 103.74 & 186732000 & 65.85 & 197550000 \\
\hline Plant & 37.13 & 222.78 & 101.64 & 609.84 & 104.91 & 629.46 \\
\hline
\end{tabular}

Source: Own data collection and calculation

the change in influential factors. Block-based plastic tunnel responds less sensibly (indeed, elasticity indicators are slightly higher than this). This is due to the fact that its investment capital need is much lower besides its NPV approaching the value of greenhouse.

\section{Results of the scenario analysis}

Among the sensitivity tests, we also conducted a scenario analysis in which we developed optimistic, realistic and pessimistic variants. In each case, we changed the same three factors. These are factors that are most likely to change from year to year. The first is yield. For each of the three growing technologies we collected data from two companies and for 5 years. The yield of the realistic version represented the values calculated for the average models introduced (the average of 5 years).
The average yield of the best three years of the studied technologies represented the optimistic scenario, while the worst three-year average was the yield of the pessimistic scenario. The second factor was price. In optimistic and pessimistic cases, the average of the worst 2 years and the best 2 years was the base in a monthly breakdown (ie. we set optimistic and pessimistic prices for each month). The third factor was the change in wage, minimum wage was the base of the optimistic scenario (wages and contributions), which is HUF 950/hour. In the pessimistic scenario, the highest gross wage (HUF $1800 /$ hour) in the technologies studied was the base. The three factors were selected on the basis of the elasticity analysis (Table 4).

After the analysis, it is clear that in the pessimistic scenario none of the investments for the growing technology returns in the supposed 15 years without subsidy. Only traditional plastic tunnel returns in 15 years with a subsidy of $50 \%$. 
Among the scenarios, the favourable factors contributed positively to the investment of all the growing technology in optimistic scenario, as all the indicators show positive tendency. Investments return in the 3rd and 4th year without subsidy in all cases. With subsidy, NPV for all the three technologies is positive from the second year. Modern greenhouse has the highest NPV value in all cases.

It is a clear conclusion that each investment is profitable in realistic and optimistic cases, but in the pessimistic scenario, in case of unfavourable changes in factors, they are uneconomical without subsidy. Therefore, it is important to place emphasis on the use of subsidies and the maintenance of the high level of production.

\section{Critical value test}

Sensitivity analysis can not only focus on the analysis of different parameters of the economic and natural environment, i.e. yield, quality and sales price, and their impact on results, but it can also determine the thresholds of the main variable factors under "ceteris Paribus" - the investment is still profitable. These are critical evaluations (Table 5).

Table 5 shows the values of the main factors influencing profitability where NPV at different growing technologies is at zero with a $5 \%$ calculative interest rate. It is important to note that these values are not sufficient to achieve good, but 'not yet unprofitable' production. In the first column, you can see how much percent of deterioration is acceptable compared with the realistic values of the factor so that production does not turn into an uneconomical range.

It is clear that change in price of fertilizers would be the smallest change under traditional plastic tunnel because if prize fertilizers were increased by $129 \%$ compared to the current prices, the net present value of the investment would be 0 . Some \% change in yield and sales price would trigger unprofitability. If the current yield of $31.1 \mathrm{~kg}$ decreased by $9.47 \%$ - less than $3 \mathrm{~kg} / \mathrm{m}^{2}$-, the investment would no longer realize positive NPV. In case of sales price, this change is maximum $7.7 \%$

In the case of a block-based plastic tunnel, the price of fertilizers has the least impact on the profitability of the investment since an unfavourable change of $356 \%$ could happen. This change has no real chance. The most influential factor of this growing technology is yield and price tendency. Regarding yield, a reduction of $23 \%$ could make the investment unprofitable. The current yield may drop by a maximum of $10 \mathrm{~kg} / \mathrm{m}^{2}$, but under closed and up-to-date technology such loss of yield isn't typical on a long basis. The accepted increase in price is HUF $19.58 / \mathrm{kg}$.

If we look at the critical value of modern greenhouse we can see that the slightest change may occur in yields and selling prices. Compared to traditional plastic tunnel, higher fluctuation is acceptable, but the value is lower than for blockbased plastic tunnel. 17\% reduction in yield may trigger value of 0 for NPV of the investment. Under the above-mentioned calculative interest rate of $5 \%$, an investment capital need of $65 \%$ higher than the current one would make our investment unprofitable.

As a conclusion, profitability of traditional plastic tunnel responds the most sensitively to changes while block-based plastic tunnel and modern greenhouse can withstand much higher - and almost the same - change in influential factors without becoming unprofitable.

\section{Conclusions}

My main objective was to determine how efficient and under what parameters forced tomato production can be performed in different technologies. My objective answered which method is the most effective, what advantages and disadvantages these technologies have, and from a costeffective perspective, which version should be chosen.

After evaluating the different types of growing technology, we compared their results to achieve the objective. The highest yield can be gained under modern greenhouse. Its yield of $57.4 \mathrm{~kg} / \mathrm{m}^{2}$ is $22 \%$ higher than yield under block-based plastic tunnel and $85 \%$ higher than yield under traditional plastic tunnel. Due to the length of the production period, yields aren't distributed equally under technologies. Higher yields and revenue are due to later harvesting under traditional plastic tunnel, therefore goods are sold at lower prices. Direct cost-profitability ratio for traditional plastic tunnel is $13 \%$ which is $23-24$ percentage points lower than for block-based plastic tunnel (36\%) and modern greenhouse $(38 \%)$. This profitability was gained by a contribution margin of HUF $798 / \mathrm{m}^{2}$ for traditional plastic house, HUF 2 433/m² for block-based plastic tunnel and HUF 3 293/ $\mathrm{m}^{2}$ for modern greenhouse.

More effective and economically more well-founded decisions can be made for investment in greenhouse if $50 \%$ non-refundable subsidy is taken into account because the especially high investment capital need of greenhouse is influenced by the investment subsidy. The cost-benefit analyses, investment-profitability calculations and sensitivity test suggest that modern greenhouse has the most efficient and profitable parameters. Expected investment subsidies provide even more favourable conditions for the efficiency and feasibility of the investment. It is a clear conclusion that each investment is profitable in realistic and optimistic scenarios, but in a pessimistic scenario - in case of unfavourable changes in influential factors - without subsidy production is unprofitable, so great emphasis should be placed on leveraging subsidies and maintaining high production standards.

\section{References}

AKI (2016): Agrárgazdasági Kutató Intézet, Agrárpiaci jelentések. Zöldség, Gyümölcs és Bor 20(10): 6 . p. Agrárgazdasági Kutató Intézet. Budapest.

Apáti, F. (2007): A jó színvonalú magyar és német almatermesztés összehasonlító gazdasági elemzése. Doktori értekezés. Debrecen. 149. p.

Apáti, F. (2009): The comparative economic analysis of Hungarian and German apple production of good standard. International Journal of Horticultural Science 15(4): 79-85.

Brealy, R. A., Myers, S. C. (2005): Modern vállalati pénzügyek. Panem Könyvkiadó. Budapest. 127-147. p.

Castle, E. N., Becker, M. H., Nelson, A. G. (1992): Farmgazdálkodás. Mezőgazda Kiadó. Budapest. 479. p.

Czerván, Gy. (2014): Zöldség-gyümölcs ágazati stratégia, 2014-2020. Agrofórum. 1. sz. 20-21. pp.

Gulyás, J. (2012): A talajnélküli hajtatás lehetősége a kislégterü termesztő berendezésekben. Zöldséggyümölcs Piac és Technológia. A Magyar Paprika Napja. 21-22. p. 
Horváth, P. (1997): Beruházás-gazdaságossági számítások. In: Controlling - Út egy hatékony controlling rendszerhez. Közgazdasági és Jogi Könyvkiadó. Budapest. 85-97. p.

Kicska, T., Apáti, F. (2015): A hazai zöldségágazat fejlödési tendenciái (2. rész) Zöldség-Gyümölcs Piac és Technológia 3: 5. p.

Kicska, T. (2015): A hazai zöldségágazat fejlődési tendenciái (1. rész) Zöldség-Gyümölcs Piac és Technológia 2: 5. p.

Ledó, F., Apáti, F. (2016): A zöldség-gyümölcs ágazat munkaerő-helyzete. In.: Zöldség-Gyümölcs Piac és Technológia. Budapest. 2016/október. 36. p.
Pfau, E. (1998): A mezőgazdasági vállalkozások termelési tényezői, erőforrásai. Vider-Plusz Bt. Debrecen. 168 p.

Szőllősi, L. (2008): A vágócsirke termékpálya 2007. évi költség- és jövedelemviszonyai. Baromfiágazat, 8(4): 4-12. pp.

Tétényi, V. (2001): Pénzügyi és vállalkozásfinanszírozási ismeretek. Perfekt Kiadó. Budapest. 550 p. 